\title{
Cash Waqf Model for Social Enterprise to Achieve Sustainable Development Goals in Indonesia
}

\author{
Najim Nur Fauziah ${ }^{1}$, Salina Kassim ${ }^{2}$ \\ ${ }^{1}$ Institute of Islamic Banking and Finance, International Islamic University Malaysia, 53100, Selangor, \\ Malaysia, najimnurfauziah@yahoo.co.id \\ ${ }^{2}$ Institute of Islamic Banking and Finance, International Islamic University Malaysia, 53100, Selangor, \\ Malaysia, ksalina@iium.edu.my
}

\begin{abstract}
Social enterprises are expected to bring significant positive impact on Indonesia's economy and may help to meet the Sustainable Development Goals (SDGs). Social enterprises empower minorities by providing more opportunities for a sustainable means of livelihood, especially for lowincome and disadvantaged groups. However, despite its potential, financial issues remain a significant barrier for the viability of social enterprises in Indonesia. Cash waqf is one of the Islamic social finance vehicles that can be used to invest and manage funds to address a variety of social issues related to the SDGs. Hence, this study aims to propose cash waqf model for social enterprise in achieving the SDGs in Indonesia and to assesses the potentials and opportunities of developing the proposed model in Indonesia. This study employs a qualitative research approach, with primary data gathered from interviews of relevant stakeholders. This study finds that, the cash waqf can solve a multitude of financial issues faced by many social enterprises in Indonesia by enlarging their pool of financing support. The possibilities and opportunities of developing the cash waqf model for social enterprise include alternative funding for social enterprise, alternative waqf for waqif, an increase in nazhir, and more effective contribution to the SDGs.
\end{abstract}

Keywords: Cash waqf, social enterprise, sustainable development goals.

\begin{abstract}
Abstrak. Usaha sosial diharapkan dapat memberikan dampak positif yang signifikan terhadap ekonomi Indonesia dan dapat membantu memenuhi tujuan pembangunan berkelanjutan atau Sustainable Development Goals (SDGs). Secara nyata, usaha sosial memberdayakan kaum minoritas dengan membuka banyak peluang pekerjaan yang berkelanjutan, terutama bagi kelompok berpenghasilan rendah dan kurang beruntung. Namun, terlepas dari potensinya, masalah keuangan tetap menjadi isu yang sangat penting bagi kelangsungan sektor usaha sosial di Indonesia. Di sisi lain, wakaf tunai adalah salah satu instrumen keuangan sosial Islam yang dapat digunakan untuk berinvestasi atau dikelola untuk mengatasi berbagai masalah sosial yang berkaitan dengan SDGs. Oleh dari itu, penelitian ini bertujuan untuk mengusulkan model wakaf tunai untuk bisnis usaha sosial guna mencapai SDGs di Indonesia dan bertujuan untuk menilai potensi dan peluang pengembangan model yang diusulkan di Indonesia. Penelitian ini menggunakan pendekatan kualitatif dengan data primer berupa wawancara dengan pemangku kepentingan terkait. Penelitian ini menyimpulkan bahwa wakaf tunai dapat menyelesaikan banyak permasalahan keuangan yang dihadapi oleh sektor usaha sosial di Indonesia dengan memberikan dukungan pembiayaan. Kemudian, kemungkinan dan peluang dari model wakaf tunai yang diusulkan di antaranya yaitu memberikan pendanaan alternatif untuk bisnis usaha sosial, menjadi alternatif untuk berwakaf bagi orang-orang yang ingin berwakaf, meningkatkan jumlah nazir di Indonesia dan berkontribusi lebih untuk SDGs.
\end{abstract}

Kata kunci: Sustainable development goals, usaha sosial, wakaf tunai.

\section{INTRODUCTION}

One of the key reasons for the UN Millennium Goals' failure was the extreme poverty found in SubSaharan African countries with large Muslim populations in the midst of the goals' implementation (Easterly, 2009). None of the countries achieved a single goal, leading to a rethinking of indigenous solutions and the setting up new plans, this time, in the form of the sustainable development goals (SDGs). The SDGs were launched in 2015 with the objective to produce a set of universal goals to

AL-MUZARA'AH Special Issue 2022

(ISSN p: 2337-6333; e: 2615-7659)

DOI: $10.29244 /$ jam.specialissue2022.95-105

Received: 25 October 2021; Accepted: 10 January 2021 
solve a plethora of environmental, political, and economic issues, as well as other pressing challenges facing the world today (UNDP, 2016).

The SDGs, which were created to replace the Millennium Development Goals (MDGs), aim to achieve a better and more sustainable future for the world. According to the United Nations Department of Global Communications (2020), SDGs comprise 17 interconnected goals to be achieved by 2030. To sustain the level of economic growth, SDGs has been the main objective of many developing countries. Sustained economic growth can have a significant positive impact on a country's income and increase the employment level, which results in better living standards for the population.

Based on the prospective SDGs, Indonesia has been established as one of the countries with good practice in integrating SDGs in its development planning. It is clearly evident in Indonesia that through the multi-stakeholder partnership scheme involving the government, the philanthropy sector, and the academia, there exists an institutional arrangement to support the SDGs implementation and their alignment programmes with Indonesia's national priorities. The partnership scheme also encourages good practice in alternative financing through the stakeholders' financial support for the SDGs programmes (UNDP, 2017).

An example of this is the successful project emerging out of the Islamic social finance stage, Indonesia's National Zakat Agency (Indonesia: Badan Amil Zakat Nasional, abbreviated: 'BAZNAS'). Collaborating alongside the United Nations Development Programme (UNDP), the two prominent institutions work together on zakat collection for the SDGs. Projects initiated by BAZNAS and the UNDP include scholarship, education, charity, health services, disaster response, and microfinancing (Noor and Pickup, 2017). Based on the successful zakat collection's successful efforts, Bahuet and Sopacua (2018) argued that waqf is another Islamic social finance instrument that can support the fulfilment of the SDGs (Bahuet and Sopacua, 2018). In addition, Littlewood and Holt (2018) stated that, for a country to achieve all SDGs, the government, businesses and the third sector are required to collaborate closely.

As one of the Islamic social finance instruments, cash waqf has created a significant impact on a community's socio-economic welfare, particularly providing financial help for people in need. According to a study by Zain and Ali (2017), cash waqf helps society immensely, from providing basic facilities to the public, including social, health, environmental, education and infrastructures. In addition, cash waqf could support the society from a religious, humanitarian or public welfare ground (Rusydiana and Devi, 2018). Indeed, cash waqf has a direct positive effect to enhance the conditions of the poor so that they can take care of themselves and, at the same time, effectively accommodates the issue of poverty with its new and comprehensive approach.

On top of that, social enterprises, which differentiated themselves from the mainstream (state acronym's full name) MSMEs of their business, have an immense potential to achieve all SDGs by 2030. A study by Littlewood and Holt (2018) upheld that social enterprises have a significant positive role in achieving the SDGs. Social enterprises are defined as a combination of the business and the social sector, with the primary objective of creating social impacts while simultaneously being financially sustainable (Rogerson et al., 2013). Evidently, social enterprises are characterised by their diverse social missions, from opening up greater inclusive job opportunities for different minority groups, specifically women and people with disabilities, to alleviating poverty and wealth inequalities (British Council and UN ESCAP, 2018).

A study by Littlewood and Holt (2018) argued that social enterprises could significantly contribute to the SDGs in many ways. Nevertheless, despite assuming obvious advantages to support the SDGs, social enterprises' lack of financial support still poses a significant issue in their development (British 
Council and UN ESCAP, 2018). Thus, a solution to the social enterprise difficulties is required to achieve the better economy and the SDGs.

Therefore, to advance the SDGs, this article intends to develop cash waqf model for social enterprise to solve a multitude of financial issues faced by many social enterprises in Indonesia by enlarging their pool of financing support. Besides, this article assesses the potential and opportunity of developing the proposed model in Indonesia.

\section{LITERATURE REVIEW}

\section{Social Enterprise Theory and Practice}

Determining the definition of social enterprises is undoubtedly an indispensable component of this study. However, no standardised definitions for social enterprises could be found due to the fragmented nature of the business. Several countries have established a definition for social enterprises. Yet, they, too, failed to reach an agreed global definition for the business model. This lack of clarity turns many social entrepreneurs to eschew the task of defining social enterprises since it has proven to be too tedious for many.

Nevertheless, few scholars have tried to rigorously elaborate an elementary sketch of social enterprises, conceptualised differently by different authors. social enterprises are defined as social businesses with social impacts objectives and use a social-mission-embedded business model to deliver their social missions, balance their profitability and social impacts to reinvest profits businesses (Siregar et al., 2015). This view is supported by ANGIN (2016), which stated that social enterprises aim to generate market-based revenues and profitability to sustain their businesses, equipped with a solid mission to solve a plethora of social and environmental issues.

Furthermore, with reference to their strategic role in the country's economy, social enterprises act as the main component of a social economy, fulfilling the complex goal of serving local and regional needs (Kim and Lim, 2017). They have considerable significant effects on the community by creating job opportunities, promoting business development and enhancing solidarity. As Siregar et al. (2015) discussed, social enterprises in Indonesia have indeed produced major positive impacts on society, such as empowering women and providing greater accessibility of schools to children, for example.

The stereotyped image of social enterprises is that the parties involved are attached to the name. Social enterprises are in essence, businesses with a specific social objective. They can be categorised to include several different types of organizations and companies. However, no particular classification exists for social enterprises. In several countries, social enterprises are often registered as cooperatives, financial institutions, foundations, or non-profit organisations. According to Siregar et al. (2015), due to the lack of legal support, social enterprises in Indonesia are routinely registered as either cooperatives, financial institutions, foundations, organisations or enterprises.

According to Force (2017) there are nine business models of social enterprises. Each type of social enterprise has a diverse business model with different business model objectives and scopes to support social enterprise's mission to benefit the community. 
Table 1 Force's social enterprise business types

\begin{tabular}{|c|c|c|}
\hline No & Business Model Types & Information \\
\hline 1 & $\begin{array}{l}\text { The Entrepreneur } \\
\text { Support Model }\end{array}$ & $\begin{array}{l}\text { In this model, social enterprise supports entrepreneurs in getting their businesses off } \\
\text { the ground by selling their services such as consulting services, training, } \\
\text { microfinancing, or technical support. }\end{array}$ \\
\hline 2 & $\begin{array}{l}\text { The Market Intermediary } \\
\text { Model }\end{array}$ & This social enterprise will help its clients to sell their products. \\
\hline 3 & The Employment Model & $\begin{array}{l}\text { This social enterprise provides job opportunity and job training for their client. The } \\
\text { revenue of this job will be allocated to those in need. }\end{array}$ \\
\hline 4 & $\begin{array}{l}\text { The Fee-for-Service } \\
\text { Model }\end{array}$ & $\begin{array}{l}\text { A social enterprise might charge directly to the customer for the socially beneficial } \\
\text { services it provides, such as hospitals and schools. }\end{array}$ \\
\hline 5 & $\begin{array}{l}\text { The Low-Income Client } \\
\text { Model }\end{array}$ & $\begin{array}{l}\text { This social enterprise offers social services for low-income people, especially for the } \\
\text { healthcare program. }\end{array}$ \\
\hline 6 & The Cooperative Model & $\begin{array}{l}\text { This model is a fee-based organization owned and operated by its member. They } \\
\text { provide the membership service for the same need and goal. }\end{array}$ \\
\hline 7 & $\begin{array}{l}\text { The Market Linkage } \\
\text { Model }\end{array}$ & $\begin{array}{l}\text { Instead of selling their client products, the social enterprise will link their client to } \\
\text { the markets to enlarge their products and services. }\end{array}$ \\
\hline 8 & $\begin{array}{l}\text { The Service } \\
\text { Subsidization Model }\end{array}$ & $\begin{array}{l}\text { Concerning this model, service subsidization is one of the most used social } \\
\text { enterprise models. The social enterprise will fund any social programs by selling } \\
\text { products or services in the marketplace. }\end{array}$ \\
\hline 9 & $\begin{array}{l}\text { The Organizational } \\
\text { Model }\end{array}$ & $\begin{array}{l}\text { This model will support the social enterprise to raise funds for a parent non-profit } \\
\text { that, in turn, runs the social programs the SE wishes to support. }\end{array}$ \\
\hline
\end{tabular}

Source: Force, 2017.

In the meantime, Westaway (2012) classified social enterprise business separately into three forms of models: (i) Profit-purpose tension, (ii) Profit-purpose alignment and (iii) the Philanthropic business model includes donor-supported categories. In which, each of these business model types has different business categories and focuses.

Table 2 Westaway's social enterprise business classification

\begin{tabular}{|c|c|c|}
\hline $\begin{array}{l}\text { Business Model } \\
\text { Types }\end{array}$ & Categories & Information \\
\hline \multirow[t]{5}{*}{$\begin{array}{l}\text { Profit-Purpose } \\
\text { tension }\end{array}$} & Buy One Give One & $\begin{array}{l}\text { The profit earned from the customers would be allocated for donation } \\
\text { purposes to the beneficiaries. }\end{array}$ \\
\hline & $\begin{array}{l}\text { Ethical Supply } \\
\text { Chain }\end{array}$ & $\begin{array}{l}\text { This business model incorporates social and environmental objectives on } \\
\text { their services and products. }\end{array}$ \\
\hline & $\begin{array}{l}\text { Direct } \\
\text { Employment }\end{array}$ & $\begin{array}{l}\text { In this model, the social enterprise will employ the beneficiaries as a } \\
\text { worker in this organization }\end{array}$ \\
\hline & Shared Ownership & $\begin{array}{l}\text { Through this model, the employees or customers are allowed to take } \\
\text { ownership interest. }\end{array}$ \\
\hline & $\begin{array}{l}\text { Cross- } \\
\text { Subsidizations }\end{array}$ & $\begin{array}{l}\text { In this model, the business will offer low-cost products for the } \\
\text { beneficiaries and high-cost products for regular market or customer. }\end{array}$ \\
\hline \multirow[t]{6}{*}{$\begin{array}{l}\text { Profit-Purpose } \\
\text { Alignment }\end{array}$} & Freemium & $\begin{array}{l}\text { There are two distinct groups in Freemium categories: (a) free } \\
\text { service/products group (b) premium-rate fees group (Zain et al., 2021) }\end{array}$ \\
\hline & $\begin{array}{l}\text { Bottom of the } \\
\text { Pyramid }\end{array}$ & $\begin{array}{l}\text { This type of business is explicitly producing a low-cost product for low- } \\
\text { income people }\end{array}$ \\
\hline & $\begin{array}{l}\text { Two-Sided } \\
\text { Marketplace }\end{array}$ & The social enterprise will link the beneficiaries to market opportunities. \\
\hline & Sharing Economy & $\begin{array}{l}\text { Sharing economy is the concept where the social enterprise will provide } \\
\text { the beneficiaries with access to capital intensive products }\end{array}$ \\
\hline & $\begin{array}{l}\text { Consulting } \\
\text { Services to } \\
\text { Mission-Driven } \\
\text { Organisation } \\
\end{array}$ & $\begin{array}{l}\text { It is providing more services to enhance its social impacts on the } \\
\text { beneficiaries. }\end{array}$ \\
\hline & $\begin{array}{l}\text { Environmental } \\
\text { Sustainability }\end{array}$ & $\begin{array}{l}\text { This social enterprise sells its products and offers its services with energy } \\
\text { efficiency and sustainability orientation. }\end{array}$ \\
\hline Philanthropic & Donor Supported & This social enterprise will generate revenue from charities or donations. \\
\hline
\end{tabular}

Source: Westaway, 2012. 
In Indonesia, social enterprises generally are made up of micro, small and medium enterprises (MSMEs), non-profit organisations (NGOs), and co-operatives. A working report by the British Council \& UN ESCAP (2018) cited that 329,689 social enterprises are estimated to be MSMEs, 20 of them are national NGOs. At the same time, 753 of them are identified as local NGOs, and 11,563 of them identify as co-operatives. However, the official and latest data should be issued by the Ministry of Cooperatives and SMEs in order to get the actual number of social enterprises in Indonesia.

\section{Cash Waqf Theory and Practice}

Muslim scholars widely accept the term a perpetual charitable donation as waqf. Waqf means to hold, confine, prohibit, detain, prevent, or restrain while legally, it denotes to protect something by preventing it from becoming the property of a third person (Iman \& Mohammad, 2014). According to Elkhatib (2016) the majority of Islamic scholars have agreed on the following components that make a waqf valid or acceptable; (a) the founder of waqf must be 'Aqil or someone in full possession of their mental capacity, Baligh or adult, Hurr or a free person, capable of transferring the ownership of the asset or property from himself to Allah; (b) the nature of the property must be movable or immovable; (c) mutawalli or wally or a trustee; and (d) beneficiaries and a form of declaration for the waqf.

Cash waqf is also more flexible than land waqf in terms of participation, whereby almost anyone can participate by donating their money as cash waqf since there are no limitations to the amount they can contribute. Following Fauziah (2021) study, the paper argued that by donating cash waqf, the interested donors would not be burdened by the fact that they do not own a piece of land. Besides, Pitchay et al. (2018) added that cash waqf is crucial to address the problem of idle waqf and may greatly assist interested institutions developing idle waqf lands.

With regards to the cash waqf practice, The Indonesian Ulama Council (Majelis Ulama Indonesia) issued a fatwa on cash waqf on the 11th of May 2002. It is stated that donating waqf in the form of money or cash is acceptable and cash waqf is recognised lawful when distributed according to shariah principles. Besides, the principal value of a cash waqf must not be sold, gifted, or inherited (MUI, 2002).

According to the Indonesian Waqf Board, Badan Wakaf Indonesia (BWI), the potential economic impact of cash waqf collection in Indonesia is expected to reach 180 trillion rupiahs per year. In contrast, according to the total collected data on cash waqf funds from 2011 to 2018, just 31.9 million rupiahs were made each year throughout that time period (PKSK Kemenkeu, 2019). Further, Fauziah (2021) study mentioned that there are enormous opportunities for cash waqf funds to be optimised in order to improve Indonesia's economic growth.

Thus, cash waqf is an immensely beneficial tool to maximise charitable giving in an effective way to help the community achieve better economic growth (Shaikh et al., 2017). The instrument guarantees constantly available financial help for any groups that are in need, in turns, making Muslim societies more prosperous and inclusive. Plus, as stated by Sadeq (2002), cash waqf can also be used to create Muslim communities with zero poverty and environmentally sustainable societies (Mohammad, 2008).

Notwithstanding the differences between cash waqf and the SDGs - the foundation of cash waqf primarily descended from revelations, while the SDGs have no religious foundation, there exists a correlation between them. In this regard, both the SDGs and cash waqf, are concerned with the same goals of alleviating poverty, social problems, and hunger through a mechanism of wealth distributions. As elaborated by Alawode (2019), Islamic finance, which aims to contribute towards the socio-economic development of a society, is a suitable mechanism to pursue the SDGs, particularly on poverty alleviation, output increase, job opportunities creation for the poor and the vulnerable. 
One objective of the shariah is to protect the well-being of people and nature, an important part of the five fundamental objectives that make up the Shariah (maqasid sharia). This objective can be safeguarded by promoting of social justice of the SDGs (Dusuki \& Bouheraoua, 2011). The shariah objectives have a remarkable resemblance to the United Nations SDGs. This view is supported by Abdullah (2018) findings that the SDGs ultimately match with the long-term shariah objectives. He also posited that waqf could be developed into a waqf-based development plan following the SDGs framework. In addition, the author also mentioned that waqf, with its ample funds, could help support many Muslim countries achieve shariah-oriented SDGs.

\section{METHOD}

This article is a qualitative research study based on the explanatory and descriptive case study. This study employed a qualitative research design to describe and analyse the cash waqf model for social enterprise to achieve SDGs in Indonesia. The research has selected Indonesia as a case study for this research as it is one of the countries with good practice in integrating the SDGs into its development planning. In addition, primary data, interviews, were used to attain the objectives of the study.

\section{RESULTS AND DISCUSSION}

\section{Developing Cash Waqf Model for Social Enterprise}

By looking at social enterprise financial problems, cash waqf may be alternative funding to help social enterprises solve their current growth problems. As mentioned by Jalil et al. (2016), it is appropriate to use cash waqf to fund a social enterprise organization for a business project or an investment project as long as it fulfils the pillars of waqf: Waqif (donor), mauquf (asset/property), mauquf alaih (beneficiary), and sighah (declaration).

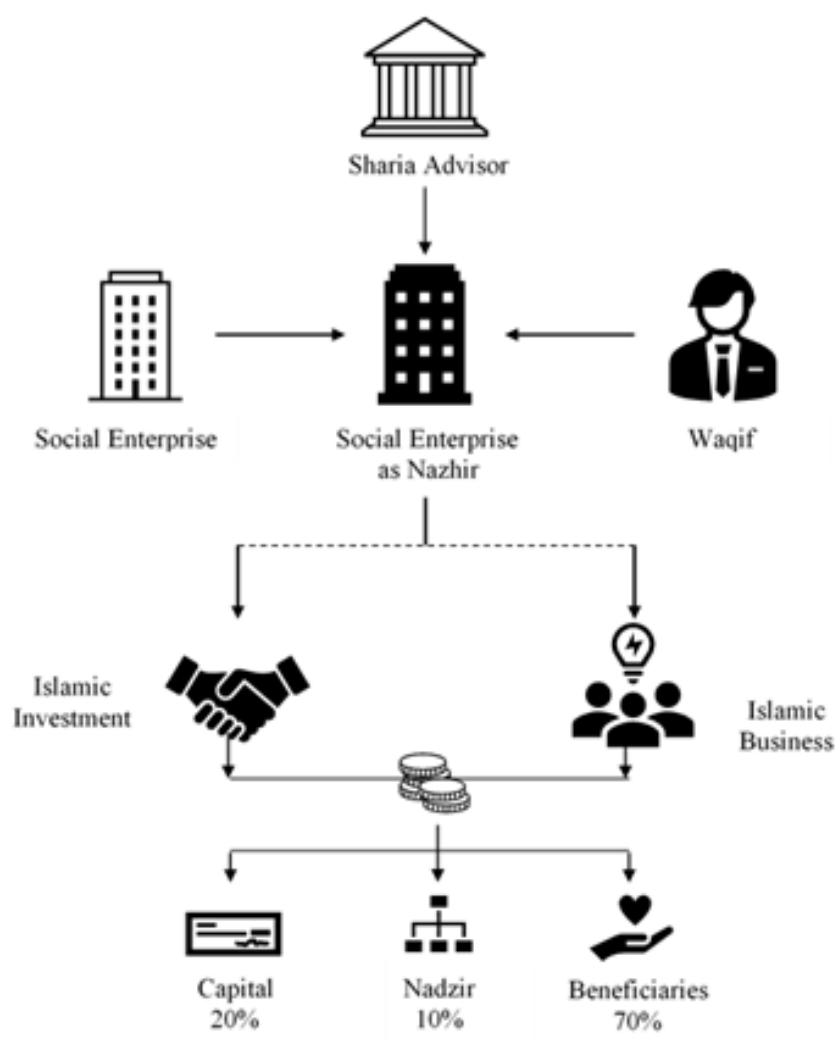

Source: Authors' Own (2021)

Figure 1 Cash waqf model for social enterprise 
In this model, it must be noted that social enterprise should has its social legal entity at the first place in order to become a registered nazhir by Indonesian Waqf Board. Following the Waqf Act number 41/2004 mentioned that an organization can become a nazhir if it is engaged in the social, educational, community, and/or Islamic religious fields. Likewise, having a legal entity that is engaged in the social, educational, community, and/or Islamic religion. In addition, as nazhir, the social enterprise is obliged to administer waqf assets; manage and develop waqf property in accordance with its purpose, function, and designation; supervise and protect the waqf property; and report the implementation of tasks to the Indonesian Waqf Board.

Then, it is suggested to social enterprise as nazhir to appoint appoint a sharia advisor to oversee the business practice and to ensure its sharia compliance activity. Following that, the social enterprise is permissible to receive the waqf from the waqif in the form of money or cash. Moreover, the social enterprise as nazhir should develop the cash waqf to fund Islamic business projects which are sharia compliance, or the social enterprise may also use the cash waqf to invest in any Islamic investment such sukuk. In this case, it is suggested to the social enterprise to select any shariah-compliant initiative with a low-risk investment rather than a high-risk investment.

Following this, the social enterprise should distribute the business and investment profit to some budget allocations in order support the SDGs achievement. The $20 \%$ of the profit should be allocated to capital in order to overcome the business project's loss due to business risks. Then, the $10 \%$ should be allocated to nazhir following the Waqf Act No.41/2004 mentioned that nazhir might receive a reward from the net proceeds the management and development of waqf assets not exceeding $10 \%$. Finally, $70 \%$ of the profit suggested to allocate to education, health, environmental, and qardhul hasan financing to support local and small businesses or any others SDGs projects.

\section{The Prospect and Opportunity of Developing Cash Waqf Model for Social Enterprise in Indonesia}

\section{Alternative financing for social enterprise business}

As proposed and developed in this report, cash waqf is the critical source of financing for Indonesia's social enterprise business. In his research Thaker (2015) stated, alternative funding using cash waqf for micro-enterprises could maximize resource allocation in the economy. Moreover, the academics concluded that this business model could be a successful option for social enterprise business due to the simplicity and flexibility of cash waqf.

\footnotetext{
"Sources of the Islamic social fund, such as waqf, are very suitable for funding social enterprises. Since the risk is much lower, as are the spirit or waqf rules, which are very supportive. Hence, the motivation of cash waqf will inspire social enterprises to become stronger in Indonesia" (Interviewee 1)
}

"With the nature of waqf in the form of money, it has a versatile side that is easier to use. Further, it also can be used to fund social enterprises" (Interviewee 2)

Also, as mentioned by Zain et al. (2021), cash waqf may be used as a social financing tool to create shariah-compliant social enterprises that end up with social-oriented contributions the community or its beneficiaries. Thus, there is an immense opportunity to use cash waqf to fund social enterprises.

\section{Alternative waqf for waqif}

Traditionally, people used to know that waqf could only be achieved by donating their land, house, or school. It means that only rich people should donate their assets as waqf. Nowadays, however, people could donate their money as a waqf, even in a small sum. It was evident that cash waqf may be a perfect option for those who want to donate just a movable asset, and they do not have movable support. Moreover, developing the cash waqf model for social enterprise in Indonesia could allow mass participation. 
"It opens up vast opportunities for people to do waqf even in a small amount. Hence it can improve the aspect of the worship of a Muslim himself. Also, cash waqf has a strategic economic contribution" (Interviewee 2)

\section{Increasing the number of nazhir}

By developing this model in Indonesia, it is believed that it could be an excellent opportunity to increase the number of nazhir in Indonesia.

"There is a great opportunity for social enterprise to become nazhir through this model so that the desires of the citizens who want to distribute their waqf can be fulfilled" (Interviewee 1)

"The Waqf Act states that nazhir has three categories: individual nazhir, nazhir legal bodies, nazhir organizations. The potential for social enterprise to become a nazhir is therefore immense, as stated in Law No 41/2004 or in Government Regulation No 42/2006, which was subsequently amended by Government Regulation No 25/2018" (Interviewee 3)

"With the increasing number of nazir in society who have productive waqf programmes, social enterprises can access their financial problems through the closest nazir" (Interviewee 4)

\section{Contribution on sustainable development goals}

It is widely agreed that social enterprise will provide work opportunities and enable disadvantaged people to increase wealth and reduce poverty. As pointed out by Thaker (2015), cash waqf, one of the redistribution schemes in the Islamic social finance system, could help increase the society's income, public consumption and investment project that could improve the economy. Besides, cash waqf could be channelled effectively to support small and medium-sized enterprises in many Muslim countries. In Nigeria, cash waqf is a significant funding source for small and medium-sized businesses to alleviate poverty (SDG 1) and improve job opportunities (SDG 8) (Sanyinna, 2018).

"The potential to introduce the cash waqf model for social enterprise in Indonesia is very great, provided that the realization of cash waqf is still very poor. With literacy, massive socialization and the presentation of the cash waqf model for social enterprise of development programmes relevant to the SDG objectives that have been successful in the community, the outlook for the proposed model is very positive" (Interviewee 4)

"Social enterprises in Indonesia have dramatically reduced the number of unemployed and have had an enormous qualitative effect than their quantitative benefits" (Interviewee 1)

Also, cash waqf benefits the citizen or a particular category of society and helps the nation cut government spending. The use of cash waqf for social enterprises could also support educational, social and health initiatives, improve the government's national development plan, eradicate poverty, provide social services, fund other social projects, and invest in diverse economic activities (Zain et al., 2021). Similarly Haron et al. (2016) stated that cash waqf could be an alternative method to achieve modern macroeconomic efficiency in a country that could help the authority reduce its spending. As a result of the cash waqf solution, there is a vast opportunity for social enterprise to facilitate decent work and economic growth and other sustainable development goals.

The 17th SDGs Partnership is a voluntary and collaborative arrangement between the various parties, both public and non-public. All participants agree to work together to achieve a common goal or to undertake a specific task and, as agreed, to share risks and responsibilities, resources and benefits. Moreover, it seems like the more people work together, the more human beings can be, and the more diverse collaborations people create, the happier people live. Refers to the "Khalifa" concept; people are called to make the revolution work on the hereafter and not work in the future. The synergy between cash waqf and social enterprises will help achieve the SDGs' goals and improve the ummah quality. As reported by the national waqf board, there are considerable opportunities for collaboration with the national waqf board or any other waqf institution to be more successful and build more social and economic well-being. 
"Social enterprises can cooperate as nazhir with the Indonesian Waqf board. In his capacity as supervisor and regulator, the Indonesian Waqf board could guide nazhir" (Interviewee 3)

"The contribution of waqf in Indonesia is quite large, as evidenced by the fact that BWI can help institutions that manage hospitals and even have returned profits to the community" ((Interviewee 1)

Table 3 Contribution of proposed cash waqf model for social Enterprise to SDGs in Indonesia

\begin{tabular}{|c|c|c|c|}
\hline SDGs & Contribution & SDGs & Contribution \\
\hline 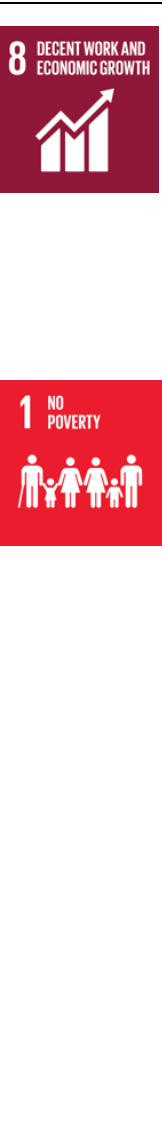 & $\begin{array}{l}\text { Social Enterprises } \\
\text { could open more job } \\
\text { opportunities to all } \\
\text { ages, where it can } \\
\text { promote productive } \\
\text { employment, decent } \\
\text { work for all, and } \\
\text { economic growth } \\
\text { Social enterprises can } \\
\text { access easy financing } \\
\text { and increase their } \\
\text { business performance } \\
\text { and productivity }\end{array}$ & 17 PARTERSHPS & $\begin{array}{l}\text { Since social enterprises } \\
\text { can get accessible and } \\
\text { easy financing to sustain } \\
\text { their business, the } \\
\text { poverty gap will be } \\
\text { reduced. } \\
\text { This proposed model will } \\
\text { invite more waqif or } \\
\text { donors to collaborate and } \\
\text { work together to achieve } \\
\text { a common goal or } \\
\text { undertake a specific task } \\
\text { and as agreed, share risks } \\
\text { and responsibilities, } \\
\text { resources and benefits. } \\
\text { This will connect among } \\
\text { social entrepreneurs, } \\
\text { waqif or donors, and } \\
\text { potential investors. This } \\
\text { will develop the } \\
\text { necessary networks for } \\
\text { future cash waqf and } \\
\text { other Islamic social } \\
\text { finance development. }\end{array}$ \\
\hline
\end{tabular}

Source: Authors' Own, 2021.

\section{CONCLUSION}

The salient finding of this paper is that cash waqf can represent an essential source for social enterprise financing to achieve SDGs in Indonesia. Cash waqf may be a solution to the social enterprise's financial problem. It could be incorporated into cash waqf model for social enterprise. Moreover, regulators and scholars have pointed out a range of things that need to be addressed when designing a model, such as nazhir professionalism and competence in managing cash waqf. Further, the model indicates having immense potential to achieve SDGs in Indonesia. These possibilities and opportunities include alternative funding for social enterprise, alternative waqf for waqif, an increase in nazhir, and contribution on SDGs.

Despite encouraging a good achievement and good results and a sound theoretical framework, there are a number of areas where policy interventions or better policy effectiveness are needed to enable social enterprises generates cash waqf financing. Establishing the legal form and regulations for cash waqf management, particularly for social enterprise, to avoid business fraud and providing some training skills for newly registered nazhir, particularly for social enterprises, to increase their 
knowledge of waqf cash are just a few examples. Apart from that, social enterprises must strengthen its workers' quality to increase the social enterprise's management's professionalism.

\section{REFERENCES}

Abdullah, M. (2018). Waqf, sustainable development goals (SDGs) and maqasid alshariah. International Journal of Social Economics.

Alawode, A. A. (2019). Islamic finance and the SDGs: financial stability perspectives. In 19th Islamic Financial Stability Forum.

[ANGIN] Angel Investment Network Indonesia. (2016). Social Finance and Social Enterprises: A New Frontier for Development in Indonesia [online]. Retrieved 2021 Jun 6 from https://www1.undp.org/content/dam/indonesia/2017/doc/INS-SF\%20Report2\%20ANGIN.PDF.

Bahuet, C, \& Sopacua, J. A. (2018 March 19). SDGs in Indonesia: 2018 and beyond. The Jakarta Post. https://www.thejakartapost.com/news/2018/03/19/sdgs-indonesia-2018-and-beyond.html.

British Council \& UN ESCAP. (2018). Building an Inclusive and Creative Economy Developing an Inclusive and Creative Economy [online]. Retrieved 2021 Jun 6 from https://www.britishcouncil.org/sites/default/files/the_state_of_social_enterprise_in_indonesia_b ritish_council_web_final_0.pdf.

Dusuki, A. W. \& Bouheraoua, S. (2011). The framework of maqasid al-shari'ah and its implication for Islamic finance. ICR Journal, 2(2), 316-336.

Easterly, W. (2009). How the millennium development goals are unfair to Africa. World development, 37(1), 26-35.

Elkhatib, M. (2016). Waqf, Its Rules and Applications in Islamic Finance. (March), 0-12. (Doctoral Dissertation, Global University, Doha, Qatar).

Fauziah, N. N. (2021). Developing cash waqf model as an alternative financing for social enterprises to support decent work and economic growth in Indonesia. Turkish Journal of Islamic Economics, 8(Special Issue), 195-217. https://doi.org/10.26414/A2759.

Force, A. G. (2017). 9 Business Model Examples for Social Enterprises [online]. Retrieved 2021 Jun 6 from https://changecreator.com/9-business-model-examples-social-enterprises/.

Haron, M., Kamarudin, M. K., Fauzi, N. M. A., Ariff, M. M., \& Zainuddin, M. Z. (2016). Cash waqf collection: any potential factors to influence it?. International Journal of Business, Economics and Law, 9(2), 27-33.

Iman, A. H. M. \& Mohammad, M. T. S. H. (2014). Waqf Property. Concept, Management, Development and Financing. Johor Bahru (MA), UTM Press.

Jalil, M. I. A., Yahya, S., \& Pitchay, A. A. (2016). The contemporary model of waqf structure. In The International Conference on Islamic Leadership and Management, Uiversity Islam Sultan Sharif Ali, Brunei.

Kim, D. \& Lim, U. (2017). Social enterprise as a catalyst for sustainable local and regional development. Sustainability, 9(8), 1-15. https://doi.org/10.3390/su9081427.

Littlewood, D. \& Holt, D. (2018). How social enterprises can contribute to the sustainable development goals (SDGs) - A conceptual framework. Contemporary Issues in Entrepreneurship Research, 8, 33-46. https://doi.org/10.1108/S2040-724620180000008007.

Mohammad, M. T. S. (2008). Sustaining the means of sustainability: The need for accepting wakaf (waqf) assets in Malaysian property market. In the 14th Annual Conference of the Pacific Rim Real Estate Society, (September), 1-17.

[MUI]. Majelis Ulama Indonesia (2002). Fatwa Wakaf Uang MUI. Jakarta (ID), MUI.

Noor, Z., \& Pickup, F. (2017). The role of Zakat in supporting the sustainable development goals. UNDP Brief, United Nations Development Programme, New York.

Pitchay, A. A., Thaker, M. A. M. T., Mydin, A. A., Azhar, Z., \& Latiff, A. R. A. (2018). Cooperativewaqf model: a proposal to develop idle waqf lands in Malaysia. ISRA International Journal of Islamic Finance, 10(2), 225-236. https://doi.org/10.1108/IJIF-07-2017-0012.

[PKSK Kemenkeu] Pusat Kebijakan Sektor Keuangan Kementerian Keuangan.(2019). Kajian Pengembangan Wakaf Uang Dalam Rangka Pendalaman Pasar Keuangan Syariah. Ringkasan 
Eksekutif [online]. Retrieved 2021 Jun 6 from https://fiskal.kemenkeu.go.id/kajian/2019/12/20/ 155813610857736-strategi-pengembangan-wakaf-uang-dalam-rangka-pendalaman-pasar-keua ngan-syariah.

Rogerson, A., Green, M., \& Rabinowitz, G. (2013). Mixing business and social: What is a social enterprise and how can we recognise one? In ODI Working Paper. Retrieved from https://cdn.odi.org/media/documents/8755.pdf.

Rusydiana, A. S. \& Devi, A. (2018). Elaborating cash waqf development in Indonesia using analytic network. International Journal of Islamic Business and Economics (IJIBEC), 1-13. https://doi.org/10.28918/ijibec.v2i1.1177.

Sadeq, A. M. (2002). Waqf, perpetual charity and poverty alleviation. International Journal of Social Economics, 29 (1-2), 135-151. https://doi.org/10.1108/03068290210413038.

Sanyinna, A. Y. (2018). Cash waqf as an effective tool of financing MSMEs for sustainable poverty alleviation: A Nigerian perspective. International Journal of Islamic Business, 13(1), 70-90.

Shaikh, S. A., Ismail, A. G., \& Mohd Shafiai, M. H. (2017). Application of waqf for social and development finance. ISRA International Journal of Islamic Finance, 9(1), 5-14. https://doi.org/10.1108/IJIF-07-2017-002.

Siregar, H., Tampubolon, N. \& Yulius. (2015). The Art of Sustainable Giving: Priorities to Accelerate Social Enterprise Growth in Indonesia. Boston (US), The Boston Consulting Group.

Thaker, M. A. B. M. T. (2015). A Proposed Integrated Cash Waqf Micro Enterprise Investment (ICWME-I) Model for Mitigating the Financial and Human Capital Development Challenges of Micro Enterprises in Malaysia. Doctoral Dissertation, International Islamic University of Malaysia, Selangor, Malaysia.

[UN DGC] United Nations Department of Global Communications. (2020). Sustainable Development Goals: Guidelines for the Use of the SDG Logo [online]. Retrieved 2021 Jun 6 from https://www.un.org/sustainabledevelopment/news/communications-material/.

[UNDP] United Nations Development Programme. (2016). The Sustainable Development Goals are Coming to Life [online]. Retrieved 2021 Jun 6 from https://www.undp.org/publications/sustainable-development-goals-are-coming-life.

[UNDP] United Nations Development Programme. (2017). Integrating the SDGs into development planning: Indonesia. Country Briefs on SDG Integration into Development Planning, 1-8.

Westaway, K. (2012). Beyond Black and White: The New Paradigm of Social Enterprise. NYU Journal of Law \& Business, 9, 439.

Zain, N. R. M. \& Ali, E. R. A. E. (2017). An analysis on Islamic social finance for protection and preservation of Maqāșid Al-Sharī'ah. Journal of Islamic Finance, 176, 1-9.

Zain, N. R. M., Fauziah, N. N., Zakariyah, H. \& Noor, A. M. (2021). Financing social enterprises through cash waqf: An innovation of business model. In Handbook of Research on Islamic Social FInance and Economic Recovery After a Global Health Crisis, 214-227). 